\title{
THE MEANING OF RELATIONSHIP QUALITY BY THE BUSINESS LEADERS: RESULTS OF A QUALITATIVE STUDY
}

\author{
Julija Jacquemod \\ RISEBA University of Applied Sciences, Latvia
}

\begin{abstract}
The aim of this research is to investigate the perception of the importance of relationship quality between the organisational leaders and their subordinates. Qualitative study methodology is used, applying the Leader-member exchange (LMX) theory as a ground for the research. The paper argues the importance of attributing the LMX to the organisational micro-foundation. Results suggest that despite of understanding of the importance of respect, trust, loyalty and other organisational assets for building effective organisational culture and competitiveness in the market, the large-size organisational leaders are not familiar with the concept of quality of relationship. Therefore, highlighting this theory and stressing the importance of relationship is particularly important in the educational process while the preparation of future leaders takes place.
\end{abstract}

Keywords: leadership, LMX, qualitative study, relationship quality.

\section{Introduction}

The organisational behaviour and management literature often tackles the question of heterogeneity of organisational performance, i.e. - what are the reasons behind it (Molina-Azorin, 2014). Organisational outcomes are the collective - level (organisational macro-level) phenomena, which are explained by means of firm procedures, structures, etc. (other collective variables). However, over the last decade, more attention is paid to micro-foundational or individual level aspects (Felin et al., 2012; Foss, 2009; Jacquemod, 2020). This opens up possibilities to look at the problem from interdisciplinary perspective; however, the question of how individual-level factors and interactions between the people contribute to organisational capabilities is still not studied much. Surprisingly, the leader - member exchange theory, which is specifically focusing on the quality of relationship between the leaders and followers, is still not observed in light of organisational micro-foundation (Jacquemod, 2020). The current research draws possibilities for so doing, as well as produces answers to the question of conceptualisations of Leader-member exchange (LMX) by business leaders by applying a qualitative approach (in-depths semi-structured interviews) which is a rarely used approach in management literature (Flyvbjerg, 
Jacquemod, 2021. The Meaning of Relationship Quality by the Business Leaders:

Results of a Qualitative Study

2006). The subject of the study is the role of leader-member exchange in the organisational outcomes, as perceived by leaders of the large-size organisations. The object is the large-size organisation leaders. Altogether, the transcripts of more than 420 minutes of interview recordings took place and the thematic analysis was performed. As a result, the subcategories and categories of LMX as regarded to organisational performance in views of business leaders, were distinguished. The data collection took place during 2019. The paper introduces with the literature review to create grounds for the formulation of the research question. Methodology part briefly explains the sample and the method used for the study, followed by results and its analysis. At the end of the paper, the conclusions and implications are discussed.

\section{Literature Review}

Recent organisational behaviour and leadership literature depicts more and more evidence and conceptualisations on the fact that leadership can be malpracticed in societal and organisational reality (Kellerman, 2004; Ketz de Vries, 2009; Cleckley, 2016; Bulatova, 2016). This research is attempting to reveal the eventual reasons for it. On the micro-level, organisations consist of individuals and interactions between them. 'Unwrapping' the factors of the individual-level may serve as an initial point in understanding the collective-level results (Felin, et al., 2015: Jacquemod, 2020). Organisational outcomes according to microfoundation movement scholars i.e. (Felin, 2015) is a result of actions of concrete individuals.

The role of leadership in understanding the organisational outcomes has been discussed broadly (Trevino, 2014; Ricard et al., 2017). It is suggested that a leader is a catalysator of change in the companies and the attitudes of top leaders echo throughout the organization (Ciulla, 2006; Ladkin, 2020). Interesting that according to study done by Indans (2010), about 90000 Latvian residents have left Latvia 'not least due to delusions in leadership and working conditions'. The present research therefore highlights the importance of the quality of relational leadership and argues its topicality for Latvian context, being not limited however to only this country as mal-practicing of leadership takes place elsewhere (Ciulla, 2006).

Leader-member exchange (LMX) theory is one of the most prominent approaches for understanding leadership (Yu, 2018), and it deals with the relationship quality between the leader and his/her subordinate, which, in turn, is understood as a two-way process based on the principle of reciprocity (Uhl-Bien et al., 2020). Leader - member exchange (LMX) theory describes how the leader and follower develop an interpersonal relationship over time as two parties influence each other (Graen \& Uhl-Bien, 1995). The terms "leader-member," 
"leader-follower," and "supervisor-subordinate or "leader - employee" and "manager-subordinate" are used interchangeably and it goes in line with LMX conceptualisation (Uhl-Bien et al., 2020). Thus, LMX being a relational leadership approach, emphasises the quality of relationships between leaders and followers.

LMX can be distinguished into high and low- quality relationship. High LMX relationships (high LMX) indicate on effective informational flow and in the basis of such exchanges there are trust, mutual respect and loyalty towards each other (Bauer and Green, 1996). Leaders and followers extend the values of mutual trust, reciprocity, respect and emotional appreciation; individuals involved in high-LMX relationships report enhanced levels of satisfaction and openness in their communication (Anand et al., 2011; Dansereau et al., 2013). Subordinates of a high-quality relationship form an "in-group" circle with their leaders. "Ingroup" members are given more interesting tasks to perform, they are empowered with greater possibilities to access organisational resources and are less controlled by the part of the leaders (Gerstner \& Day, 1997).

In case of low quality relationship, a lower level of trust takes place (Graen \& Uhl-Bien, 1995). Control is applied by the leaders towards their "outer-group" members. Low LMX subordinates demonstrate less initiative and they clearly have a disadvantaged position in terms of various job benefits and career growth. "Outer-group" subordinates have restricted access to organisational resources and are provided with less information. This eventually causes job dissatisfaction, low organizational commitment, and even an unproductive or deviant behaviour (Gerstner \& Day, 1997). Hence, low LMX relationship employs just formal contracts and they are based upon tangible assets (Dulebohn et al., 2012).

Hence, low or high LMX indicate on the quality of social exchanges between the parties. Scholars (Uhl-Bien et al., 2013) pay attention that organisational performance depends on how the parties evaluate each other. If the both parties are dedicated to construct a high-quality relationship, it contributes to higher overall work efficiency (Maslyn \& Uhl-Bien, 2001; Cogliser et al., 2009). There are studies indicating on the links between evaluation of overall organisational innovativeness and LMX (Pucetaite \& Novelskaite, 2014), organisational trust and LMX (Bulatova, 2017) as well as high job commitment and high LMX (Dulebohn et al., 2012).

It was proven that high-quality relationship affect the well-being of the employees, which, in turns is argued to be crucial for organizations' effectivity (Graen \& Uhl-Bien, 1995) and societal functioning (Bulatova, 2015). Hansen (2011) stresses the importance of studying how LMX is addressed by leaders. Current research responds to this call. It investigates how the leaders of large-size business organisations evaluate the significance of the LMX. The link between quality of dyadic relationship with organisational outcomes has been studied for 
Jacquemod, 2021. The Meaning of Relationship Quality by the Business Leaders:

Results of a Qualitative Study

a while i.e. (Graen \& Uhl-Bien, 1995). However, further investigation of understanding LMX from the perspective of individual (Norvapalo, 2014) and societal levels (Nie \& Lamsa, 2016) can still be considered (Estel et al., 2019). This paper follows Pucetaite \& Lamsa (2008) and Estel with colleagues (2019) discussion and brings in light the importance of individual leaders' responsibilities in forming high quality relationship and relates it to the cultural context. Latvian business context is interesting for a study as it represents a still young capitalistic relationship because the country has experienced the transfer to a new social formation best described by Young (2003) as a period of so-called "brutal capitalism".

The following research question was put forward: How do the leaders of large-size organisations in Latvia regard the importance of quality of their relationships with subordinates? Another research question has particularly tackled the question of how do the leaders regard the matter of being evaluated by their followers?

\section{Methodology}

For the purpose of the study, in-depth interviews with the large-size organisational leaders (which, following the tradition of managerial literature means top-management executives, see Yukl, 2018) took place. Large-size companies were addressed for the following reasons: firstly, such companies by employing the biggest number of people shape societal attitudes, draw the lines for economic development, have impact on values, technological development, and thus, can be considered as "the leaders of opinion" (Kooskora, 2008). Secondly, large companies are often positioned as top employers; they have easier access to innovation funds and are important players for the turnover of capital and thus, economic growth of the countries (European Commission report, 2017). It is argued therefore that large companies have a strong impact on the progress of economy, and according to Eurostatistics (2017), a company employing more than 250 staff is considered a large-size organisation.

As qualitative research tackles with the depth rather than breath of the phenomena (Yin, 2015), this does not require a big sample, usually 6 - 8 cases are recommended (Flyvbjerg, 2006). Ideally, achieving theoretical saturation by providing as much detail as possible involves selection of individuals or cases that can ensure that various shades of phenomenon are examined. Maximal variation strategy was therefore applied (Creswell \& Tashakkori, 2007). As to year 2019, there were 195 large-size companies (SBA, 2019), and, as a matter of fact, a thorough analysis of factors was performed to create the sample. The following categories were selected and justified by literature:

- Capital of the company: foreign capital / local capital 
- Production company/ service company

- Historical (or traditional) Latvian business/ new to Latvia's economy business

- Innovative sector/not innovative sector

- Leader gender: male - leader / female - leader

- Size of company: over 250/ over 500 employees

- Turnover of the capital: top 15 companies in high turnover/companies with comparatively low turnover

- Ethicality of industry: ethically sensitive/ethically neutral business

The semi - structured individual in-depths interviews were conducted; a total more than 420 minutes of transcripts of interviews resulted in distinguishing the themes. For confidentiality purposes the companies are not mentioned in this article. Back and forth re-reading and re-categorising them allowed further comparison of the answers and distinguishing broader categories applying the thematic analysis technique. Further, categories of behavioral practices in regards to LMX dimensions were formed.

\section{Results}

Interview results in general suggest that the leaders realise the significance of their role in creation of organisational culture, climate, and organisational innovativeness. The leaders are aware of the importance of organisational trust, respect and loyalty. Specifically, trust was found to be a well-known concept, although its true meaning and understanding of its manifestation in daily life would be needed to be checked by other research techniques rather than interviews (Jacquemod, 2020). The leaders however have stressed organisational trust as an important organisational asset, gave explanations on how it can be formed and also have emphasised the role of leadership in its regards. The terms "leader-member exchange" and "relational leadership" were found to be strange and unknown concepts. The answers indicated on misunderstanding and did not show that business leaders would consider relationship quality as an important micro-level foundation for the effective functioning of their businesses. However, putting questions back and forward and discussing together what the LMX might be, fifteen behavioural practices in regards to LMX and organisational outcomes were distinguished, please see the table below. 
Jacquemod, 2021. The Meaning of Relationship Quality by the Business Leaders: Results of a Qualitative Study

Table 1 Explorations of Categories Followed from the Interviews (created by the author)

\begin{tabular}{|c|c|c|c|}
\hline No. & Sub-category & $\begin{array}{l}\text { Leaders`behaviour } \\
\text { /theme }\end{array}$ & Citations of the interviews \\
\hline 1. & $\begin{array}{l}\text { Encouraging } \\
\text { innovative } \\
\text { thinking }\end{array}$ & $\begin{array}{l}\text { Providing support for } \\
\text { innovative ideas and } \\
\text { recognition of } \\
\text { innovative solutions; } \\
\text { Acting friendly to } \\
\text { innovative } \\
\text { performances; Being } \\
\text { helpful; } \\
\text { Providing resources } \\
\text { (time and money) to } \\
\text { implement ideas. }\end{array}$ & $\begin{array}{l}\text { "We come together to discuss a potential } \\
\text { project, and often it is risky. The idea } \\
\text { generator plays an important role, but } \\
\text { others are responsible as well, the whole } \\
\text { team is responsible, and we find money } \\
\text { for reasonable improvements." } \\
\text { "Some ideas are rubbish, but you need to } \\
\text { find words to encourage the innovator!" } \\
\text { "We would like to demonstrate that we } \\
\text { care for the environment, we participate } \\
\text { in sustainability rewards; good ideas of } \\
\text { everybody [in these regards] are } \\
\text { welcome!" }\end{array}$ \\
\hline 2. & $\begin{array}{l}\text { Stimulating } \\
\text { knowledge } \\
\text { diffusion, } \\
\text { respect for } \\
\text { mutual } \\
\text { competences }\end{array}$ & $\begin{array}{l}\text { Collecting opinion } \\
\text { before initiating the } \\
\text { changes in organisation; } \\
\text { Stimulating knowledge- } \\
\text { sharing. }\end{array}$ & $\begin{array}{l}\text { "We all have different experience, we } \\
\text { need to learn from each other [...], some } \\
\text { people transfer knowledge from } \\
\text { previous working places, [...], we need } \\
\text { to know what happens, what is our } \\
\text { common knowledge and analyse it." } \\
\text { "We know that there are professionals } \\
\text { who have been working for many years, } \\
\text { and they know exactly what the } \\
\text { organisation is doing, and they are the } \\
\text { real assets of the company" }\end{array}$ \\
\hline 3. & $\begin{array}{l}\text { Intellectual } \\
\text { stimulation }\end{array}$ & $\begin{array}{l}\text { Providing employees } \\
\text { with intellectually } \\
\text { challenging tasks. }\end{array}$ & $\begin{array}{l}\text { "People need to go to courses, } \\
\text { conferences, they need to grow!" } \\
\text { "Is hard to stimulate to learn something } \\
\text { new, but we deliberately make rotations } \\
\text { from time to time so that new skills are } \\
\text { acquired by people, and it enhances } \\
\text { communication and respect towards } \\
\text { each other" }\end{array}$ \\
\hline 4. & $\begin{array}{l}\text { Stimulating } \\
\text { personal } \\
\text { choice in } \\
\text { creative } \\
\text { decisions and } \\
\text { enhancing } \\
\text { responsibility }\end{array}$ & $\begin{array}{l}\text { Showing appreciation } \\
\text { for good solutions; } \\
\text { Giving subordinates } \\
\text { autonomy to determine } \\
\text { responsibilities of how } \\
\text { the job should be done } \\
\text { and situations handled. }\end{array}$ & $\begin{array}{l}\text { "We are trying to make it all clear, but at } \\
\text { the same time we don't like the routine, } \\
\text { and when it gets too clear it can harm } \\
\text { creativity, the tasks must be clear, but it } \\
\text { should also be a corridor for own } \\
\text { choice." } \\
\text { "Amazingly, employees usually know } \\
\text { and how to do the things! - sometimes } \\
\text { procedures come later, when the } \\
\text { decision was already found!" }\end{array}$ \\
\hline
\end{tabular}




\begin{tabular}{|c|c|c|c|}
\hline & & & $\begin{array}{l}\text { "Responsibility is something people like } \\
\text { to take, this is a true sign of loyalty, } \\
\text { sometimes is just the art not to disturb." }\end{array}$ \\
\hline 5. & $\begin{array}{lr}\text { Providing } & \text { (co- } \\
\text { creating) } & a \\
\text { vision, } & \\
\text { motivating } & \text { to } \\
\text { innovative } & \\
\text { solutions } & \end{array}$ & $\begin{array}{l}\text { Communicating an } \\
\text { explicit vision on the } \\
\text { role of innovation, } \\
\text { providing directions for } \\
\text { future activities }\end{array}$ & $\begin{array}{l}\text { "We are exploring opportunities, we are } \\
\text { generating ideas, we are putting efforts } \\
\text { in development of new ideas, we often } \\
\text { speak about it and try to motivate } \\
\text { everybody" } \\
\text { "Innovativeness must be connected with } \\
\text { the overwhelming feeling of serving a } \\
\text { big goal, we need to create it." }\end{array}$ \\
\hline 6. & $\begin{array}{l}\text { Dividing tasks } \\
\text { into tangible } \\
\text { blocks - }\end{array}$ & & $\begin{array}{l}\text { "Sometimes we don't know how to } \\
\text { solve something, but we sit and divide } \\
\text { tasks in some blocks, when is easy to } \\
\text { analyse and -later- easy to be } \\
\text { responsible." }\end{array}$ \\
\hline 7. & $\begin{array}{l}\text { Demonstrating } \\
\text { trust in } \\
\text { employee } \\
\text { competence; } \\
\text { Delegating } \\
\text { (and trusting) }\end{array}$ & $\begin{array}{l}\text { Delegating and trusting } \\
\text { professional skills, } \\
\text { encouraging decision - } \\
\text { making } \\
\text { Making allowance for } \\
\text { employees' commitment } \\
\text { when assigning tasks. } \\
\text { checking-up on people }\end{array}$ & $\begin{array}{l}\text { "If somebody wants to do things, why } \\
\text { we need to look for external } \\
\text { professionals - we have our own people, } \\
\text { who know organisation, its values, know } \\
\text { colleagues and know what is needed." } \\
\text { "It is not everything that should be } \\
\text { prescribed, each day requires many } \\
\text { decisions, and everybody must handle } \\
\text { them!" } \\
\text { "[organisation] should be able to } \\
\text { function if the manager is not there, } \\
\text { because it is essential everybody knows } \\
\text { and is able to do the right thing, and is } \\
\text { able to make competent decisions, which } \\
\text { will be in the interests of the } \\
\text { organisation and will go in line with our } \\
\text { norms". } \\
\text { "I can trust the employees, and I think } \\
\text { they can trust me". } \\
\text { "Before I have trusted more, but now I } \\
\text { see it goes to a different direction, not } \\
\text { exactly where I would like it does, shall } \\
\text { I interfere, or not? I would like to say, to } \\
\text { ask why is done this way, but it is not so } \\
\text { easy, because it is another person } \\
\text { viewpoint, and I have to respect it" }\end{array}$ \\
\hline 8. & $\begin{array}{l}\text { Creating an } \\
\text { organisational } \\
\text { culture }\end{array}$ & $\begin{array}{l}\text { Create links between } \\
\text { people, provide } \\
\text { possibilities for easy } \\
\text { communication between } \\
\text { generations and different }\end{array}$ & $\begin{array}{l}\text { "We sit altogether, at the same floor, } \\
\text { before the administration was on the } 11^{\text {th }} \\
\text { floor, and of course it enhanced the } \\
\text { differences, now we don't want it, it } \\
\text { created unnecessary distance!" }\end{array}$ \\
\hline
\end{tabular}


Jacquemod, 2021. The Meaning of Relationship Quality by the Business Leaders: Results of a Qualitative Study

\begin{tabular}{|c|c|c|c|}
\hline & & $\begin{array}{l}\text { statuses, diverse } \\
\text { departments and } \\
\text { employees. } \\
\text { Organising events, } \\
\text { meetings and holding a } \\
\text { certain atmosphere of } \\
\text { trust during the } \\
\text { meetings. }\end{array}$ & $\begin{array}{l}\text { "it is important people work at the } \\
\text { office, like this they meet others, and } \\
\text { mix with different generations, and those } \\
\text { can tell stories from the past, this } \\
\text { folklore is important part of our culture." } \\
\text { "it is important to stimulate knowledge } \\
\text { about each other,about what is going on } \\
\text { inother departments...important to } \\
\text { manage time for so doing, so people are } \\
\text { not only concerned with what they are } \\
\text { doing, and their own projects" }\end{array}$ \\
\hline 9. & $\begin{array}{l}\text { Stimulating } \\
\text { open and } \\
\text { transparent } \\
\text { communication }\end{array}$ & $\begin{array}{l}\text { Minimisation of power } \\
\text { distance and vertical } \\
\text { relationship for overall } \\
\text { organisational } \\
\text { achievements, as well as } \\
\text { correcting something, } \\
\text { somebody's behaviour } \\
\text { and enhancing personal } \\
\text { growth Insuring } \\
\text { feedback flow to } \\
\text { employees by co- } \\
\text { workers, encouraging } \\
\text { communication flow } \\
\text { between the employees } \\
\text { and direct supervisors. }\end{array}$ & $\begin{array}{l}\text { "Young people don't like to be told, we } \\
\text { create a culture of people who share } \\
\text { ideas, communicate, and raise doubts", } \\
\text { "important is that people are not scared } \\
\text { we all share the same goals, is important } \\
\text { we achieve them." } \\
\text { "Important is that the employees ask } \\
\text { questions and are not obedient". } \\
\text { "Before the management was on the } 11^{\text {th }} \\
\text { floor, but we don't want it any more, this } \\
\text { keeps the distance, somebody has to go } \\
\text { up to start to stress..." }\end{array}$ \\
\hline 10. & $\begin{array}{l}\text { Giving a } \\
\text { feedback to } \\
\text { subordinates }\end{array}$ & $\begin{array}{l}\text { Ensuring a concrete } \\
\text { feedback to everybody. }\end{array}$ & $\begin{array}{l}\text { "Sometimes you really need to be very } \\
\text { concrete, and say exactly what you } \\
\text { think, what needs to be improved; } \\
\text { otherwise it can be too soft and can be } \\
\text { misunderstood." }\end{array}$ \\
\hline 11. & $\begin{array}{l}\text { Stimulating } \\
\text { employeesto } \\
\text { provide open } \\
\text { feedback to } \\
\text { management }\end{array}$ & $\begin{array}{l}\text { Providing opportunities } \\
\text { for feedback to } \\
\text { administration, openness } \\
\text { to critique }\end{array}$ & $\begin{array}{l}\text { "Managers and leaders were scared from } \\
\text { the feedback, but then it went better, and } \\
\text { is healthy for our organisation" } \\
\text { "If leaders are really good, they are } \\
\text { recognised by time by others. } \\
\text { "I don't really care whether I am liked } \\
\text { by the employees [...], but it makes me } \\
\text { to feel great when I feel they } \\
\text { [employees] appreciated the decision, } \\
\text { especially on the sensitive matters" } \\
\text { "Sometimes is hard to hear critique, but } \\
\text { it is essential for growth, we try to turn it } \\
\text { into a positive dialogue." }\end{array}$ \\
\hline 12. & $\begin{array}{l}\text { Working on } \\
\text { organisational } \\
\text { identity }\end{array}$ & & $\begin{array}{l}\text { "In a big organisation it is hard to create } \\
\text { a common value, but once is done - } \\
\text { everything goes easier, organisation sort }\end{array}$ \\
\hline
\end{tabular}




\begin{tabular}{|c|c|c|c|}
\hline & & & $\begin{array}{l}\text { of cleans up from elements who do not } \\
\text { suit here, and attracts people with } \\
\text { similar views" } \\
\text { "we involve full organisation", new } \\
\text { product is like a new child for } \\
\text { everybody, we feel pride for it." }\end{array}$ \\
\hline 13. & $\begin{array}{l}\text { Allowing for } \\
\text { mistakes and } \\
\text { recognition of } \\
\text { moral choice } \\
\text { decisions }\end{array}$ & $\begin{array}{l}\text { Addressing morally } \\
\text { difficult cases, sensitive } \\
\text { topics and appreciation } \\
\text { of interest in these } \\
\text { matters }\end{array}$ & $\begin{array}{l}\text { "[A leader] has to distinguish [good and } \\
\text { bad] intentions, and support those who } \\
\text { try to make it better, better for all the } \\
\text { parties and society as a whole." }\end{array}$ \\
\hline 14. & $\begin{array}{l}\text { Control of } \\
\text { behaviour and } \\
\text { sanctions } \\
\text { against } \\
\text { inappropriate } \\
\text { behaviour, } \\
\text { monitoring of } \\
\text { task } \\
\text { assignment }\end{array}$ & $\begin{array}{l}\text { Providing feedback on } \\
\text { unacceptable cases } \\
\text { Attrition of individuals } \\
\text { Monitoring work } \\
\text { routines, clearness of } \\
\text { tasks and objectivity in } \\
\text { task distribution, }\end{array}$ & $\begin{array}{l}\text { "We had to fire many people who did } \\
\text { not realise the importance of our culture, } \\
\text { our norms of behaviour. Unfortunately, } \\
\text { it was nothing to do, you cannot change } \\
\text { people". } \\
\text { "Sometimes people don't have to think } \\
\text { and to be creative, ... we could do more } \\
\text { to help them to be creative, but out of } \\
\text { the direct job requirements." } \\
\text { "constant clients are the base for our } \\
\text { success, we encourage employees to } \\
\text { think in these terms" }\end{array}$ \\
\hline 15. & $\begin{array}{l}\text { Role- } \\
\text { modelling }\end{array}$ & $\begin{array}{l}\text { Being an example of } \\
\text { behaviour, value transfer }\end{array}$ & $\begin{array}{l}\text { "Employees see you and make a } \\
\text { conclusion on what is important", "you } \\
\text { really need to pay attention to what you } \\
\text { say, what you emphasise and what } \\
\text { image you create" } \\
\text { "What is discussed, how is discussed - } \\
\text { these are the values of the leaders, which } \\
\text { are getting spread around" } \\
\text { "Employees see you and make a } \\
\text { conclusion of what is important", } \\
\text { "leadership is an example" }\end{array}$ \\
\hline
\end{tabular}

Referring interview results to the LMX scale (Graen \& Uhl-Bien, 1995), fifteen leadership behaviours were distinguished and analysed in details. Interesting for example, was the category of "providing the feedback", as it was divided into feedback to management (by lower status individuals) in the form of raising openly the questions, doubts, concerns - it was emphasized in four interviews. While another feedback was clearly turned towards employees, and it had a connotation of sanctionability. As such, it was overlapping with the category of "controlling behavior". Organizing feedback for individual growth is clearly emphasised by Yukl (2008). Literature also suggests that feedback can also be considered as a sign of recognition and the readiness for supportability (Kaptein, 2008), knowledge sharing, and intellectual stimulation (Dulebohn et al., 2012). 
Jacquemod, 2021. The Meaning of Relationship Quality by the Business Leaders:

Results of a Qualitative Study

Specifically, one of the leaders has stated that he hates obedient employees, a "communication should be clear, open, and without unnecessary boundaries". Other comment emphasised that "communication should be open in a sense of sharing different views and without fears that something might seem silly, or somebody might seem strange; if there is a question, it has to be asked". Reduction of power hierarchy was also mentioned in another interview - as a matter of office location, namely - "managers should not be located somewhere on the other floor and be unreachable".

In interviews, individual achievements and individual growth were not stressed anyhow though, except for one business leader (from IT sector). The leaders were emphasising the importance of feedback, but how they actually recognise and evaluate the effort of the employees was not mentioned. Mostly, the feedback was connected to performance matching it to organisational goals (emphasising the importance of customer satisfaction): "We need to say how the work is done, and leaders who are able to do so, really good leaders, I remember some from my early days, they gave me good advices, and encouraged me, I am trying to do something similar"... "Good leaders remind of importance of client satisfaction.”

One more perspective of feedback was connected with being able to criticise directly: "It is important to be able to speak with all the employees, on different levels and sometimes give a very concrete feedback...". This indicates that giving a feedback is more associated with the ability of the leader to express dissatisfaction and indicate on wrong-doings of the employees. Literature however suggests that feedback contains "rewarding for appropriate behaviours" (Foss, 2009), which was almost not addressed by the leaders here.

Another interesting aspect highlighted in interviews by the leaders who participated in this research, was "monitoring of work flow". In the centre of discussions there was however a leader with his/her leadership skills, and not the employee with his/her potentials and needs. Recognising potentials and efforts of the employees, being proud of their professional achievements was not in the scope of discussions. One statement indirectly showed that the organisation consists of professionals, but it was not personalised, and therefore it is hard to conclude if the subordinates actually feel being appreciated.

\section{Conclusions}

The concepts of "quality of relationship" and "relational leadership" are not common for business leaders. However, separately the dimensions of LMX such as mutual trust, loyalty, respect were mentioned by the leaders as important assets of organisational life. However, loyalty and trust are expected from employees 
towards their employer rather than the other way round - leaders' duties and obligations towards followers.

Business leaders are aware of their role in organisational achievements and they emphasised the value of strong organisational culture, organisational innovativeness, and trust. But the role their employees play in having organisational outcomes was not so stressed. This goes in line with the arguments of the management (Kellerman, 2004; Ketz de Vries, 2009) and business ethics (Ciulla, 2006) literature that certain self-focused behaviour is observed in leadership practice.

The perception of leaders' role in creating leader-member relationship is not so clear. The answers did not indicate on leaders' concern of how they are perceived by followers. Followers' needs and expectations towards their leaders were not revealed in any of the conducted interviews. Neither the wording Leader's caring attitude was mentioned once. However, the difficulty of extending emotional support and empathy towards subordinates was discussed. This serves as an evidence of the actuality of the current research and addresses the call for the LMX theory popularisation in a country with still young business context.

Practical novelty of the research resulted in fifteen leadership behaviours explanations of LMX challenges in a daily life. For instance, it was mentioned that employees should have opportunity to grow and make mistakes (to a reasonable extent). Support for experimentation and brainstorming should be given. Employees should be encouraged to speak out, not being afraid of condemning comments from colleagues or a strict power hierarchy, just to mention few.

It can be recommended to stimulate transparent communication, encouragement of voicing behaviour from the parts of subordinates. Respect to employee competences should take place; attentive attitude towards employees' feelings can be suggested as well, as it forms an emotional aspect of relationship.

Possibility to provide a feedback to management contributes to the employee's willingness to be engaged, support organisational values and readiness to support their leaders. This creates a deeper, 'emotional' quality of the leadermember relationship, thus encouraging subordinators to provide the feedback permits managers to make corrections of own behaviours and decisions, becoming better persons and better leaders. So, it can be suggested to the business leaders to be more open to critique and facilitate the feedback of the employees towards the management.

Educational process of business schools should highlight the importance of LMX theory; soft-skill study courses might address LMX theory from different angles. Educating society in large, the values of mutual respect and trust (they are in the core of qualitative LMX) should be addressed and illustrated by good 
Jacquemod, 2021. The Meaning of Relationship Quality by the Business Leaders:

Results of a Qualitative Study

examples and practices of outstanding leadership by policy-makers and non governmental organisations and state representatives.

In sum, for Latvian business environment, which is still young, some business paradigms (as quality of relationship) has to be approached and put into practice. The current study contributes to the understanding of the LMX as related to the context phenomena.

The aim of the qualitative research was to explore how the business leaders of large-size organisations in Latvia consider the importance of Leader-member exchange or relationship quality and draw some conclusions and implications for practitioners. The aim of the study is accomplished as model of fifteen leadership behaviours on how the relationship quality can be connected to organisational outcomes is proposed. Limitations of the study mainly tackles the question of the choice of the sample - only large-size organisations were in the scope as it limits the generalisability of the findings. The relationship quality can be perceived differently in small and medium-size businesses. This study is a demonstration of the work in progress, and further research needs to involve small and mediumsize businesses, as well as quantitative approach can take place to study how LMX is perceived by the employees of the organisations in scope.

\section{References}

Anand, S., Hu, J., Liden, R. C., \& Vidyarthi, P. R. (2011). Leader-member exchange: Recent research findings and prospects for the future, 311-325. In: A. Bryman (Ed.) The Sage Handbook of Leadership. London: Sage Publications.

Bauer, T. N., \& Green, S. G. (1996). Development of leader-member exchange: A longitudinal test. Academy of management journal, 39(6), 1538-1567.

Bulatova, J. (2016). Morality as an Index of Mental Health of the Organisation: Building a model of healthy leadership. In: M.C.C. Arruda and B. Rok (Ed.) Understanding Ethics and Responsibilities in a Globalising World. Springer: Switzerland.

Cleckley, H. M. (2016). The Mask Of Sanity: An Attempt To Clarify Some Issues About the SoCalled Psychopathic Personality (3rd Ed). Pickle Partners Publishing.

Cogliser, C. C., Schriesheimb, C., Scandura, T. A., \& Gardnera, W. L. (2009). Balance in Leader and Follower Perceptions of Leader-Member Exchange: Relationships with Performance and Work Attitudes. The Leadership Quarterly, 20(3), 452-465.

Creswell, J.W., \& Tashakkori, A. (2007). Developing Publishable Mixed Methods Manuscripts. Journal of Mixed Methods Research, 1(2), 107-11.

Ciulla, J. B. (2006). Ethics: The heart of leadership. In: J. B. Ciulla (Ed.). Responsible leadership, 37-52. Routledge.

Dansereau, F., Seitz, S. R., Chiu, C.-T., Shaughnessy, B., \& Yammarino, F. J. (2013). What makes leadership, leadership? Using self-expansion theory to integrate traditional and contemporary approaches. The Leadership Quarterly, 24, 798- 821.

Dulebohn, J. H., Bommer, W. H., Liden, R. C., Brouer, R. L., \& Ferris, G. R. (2012). A MetaAnalysis of Antecedents and Consequences of Leader-Member Exchange: Integrating the Past With an Eye Toward the Future. Journal of Management, 38, 1715-1759. 
European Commission. (2012). European Commission Report. Retrieved from: https://ec.europa.eu/economy_finance/publications/european_economy/2012/index_en. htm

European Comission. (2019). SBA Facts. file://C:/Users/User/AppData/Local/Temp/Latvia\% 20\%20SBA\%20Fact\%20Sheet\%202019.pdf, accessed: 07.09.2019.

Felin, T., Foss, N. J., Heimeriks, K. H., \& Madsen, T. L. (2012). Microfoundations of routines and capabilities: Individuals, processes, and structure. Journal of Management Studies, 49(8), 1351-1374.

Felin, T., Foss, N. J., \& Ployhart, R. E. (2015). The Microfoundations Movement in Strategy and Organization Theory. The Academy of Management Annals, 9(1), 575-632.

Flyvbjerg, B. (2006). Five misunderstandings about case-study research. Qualitative inquiry, 12(2), 219-245.

Foss, N. J. (2009). Alternative research strategies in the knowledge movement: from macrobias to micro-foundations and multi-level explanation. European Management Review, 6, 16-28.

Gerstner, C. R., \& Day, D. V. (1997). Meta-analytic review of leader- member exchange theory: Correlates and construct issues. Journal of Applied Psychology, 82, 827-844.

Graen, G. B., \& Graen, J. A. (Eds.). (2006). Sharing network leadership, 4. Greenwich: Information Age Publishing.

Graen, G. B., \& Uhl-Bien, M. (1995). Relationship-Based Approach to Leadership: Development of Leader-Member Exchange (LMX) Theory of Leadership over 25 Years: Applying a Multi-Level Multi-Domain Perspective. Leadership Quarterly, 6, 219-247.

Hansen, S. D. (2011). Ethical Leadership: A Multifoci Social Exchange Perspective. The Journal of Business Inquiry, 10, 41-55.

Indans, I. (2010). Global Economic Recovery and Emigration: News from Latvia. Project ENACTEnacting European Citizenship (Nr.217504), coordinated by Open University.

Jacquemod, J. (2020). Leader-Member exchange and organisational trust as microfoundations of organisational innovativeness. RISEBA University of Applied Sciences.

Kaptein, M. (2008). Developing and testing a measure for the ethical culture of organisations; the corporate ethics virtue model. Journal of Organisational Behaviour, 29(7), 923-47.

Kellerman, B. (2004). Bad Leadership: What It Is, How It Happens, Why It Matters. Boston, Harvard Business Publishing.

Ketz de Vries, M. (2009). Reflections on Character and Leadership. Wiley and Sons.

Kooskora, M. (2008). Understanding Corporate Moral Development in the Context of Rapid and Radical Changes. The Case of Estonia. Academic dissertation defended in University of Jyväskylä.

Ladkin, D. (2020). Rethinking leadership: A new look at old questions. Edward Elgar Publishing.

Liden, R. C., \& Maslyn, J. M. (1998). Multidimensionality of leader-member exchange: An empirical assessment through scale development. Journal of management, 24(1), 43-72.

Lord, R. G., \& Maher, K. J. (1991). Cognitive theory in industrial and organizational psychology. Handbook of industrial and organizational psychology, 2, 1-62.

Maslyn, J.M., \& Uhl-Bien, M. (2001). Leader-member exchange and its dimensions: Effects of self-effort and other's effort on relationship quality. Journal of Applied Psychology, 86(4), 697-708.

Molina-Azorín, J. F. (2014). Microfoundations of strategic management: Toward micro-macro research in the resource-based theory. Business Research Quarterly, 17, 102-114. 
Jacquemod, 2021. The Meaning of Relationship Quality by the Business Leaders:

Results of a Qualitative Study

Norvapalo, K. (2014). The Quality and Development of the Leader-Follower Relationship and Psychological Capital. A Longitudinal Case Study in a Higher Education Context. University of Jyvaskyla.

Nie, D., \& Lamsa, A. M. (2015). The leader-member exchange theory in the Chinese context and the ethical challenge of guanxi, Journal of Business Ethics, 128 (4), 851-861.

Pueetaite, R., \& Novelskaite, R. (2014). The Mediating Effect of Organisational Trust in the Relationship Between Leader Member Exchange and Organisational Innovativeness. Economics and Management, 19 (2), 194 - 201.

Ricard, L. M., Klijn, E. H., Lewis, J. M., \& Ysa, T. (2017). Assessing public leadership styles for innovation: A comparison of Copenhagen, Rotterdam and Barcelona. Public Management Review, 19(2), 134-156.

Trevino, L.K. den Nieuwenboer, N. Kreiner, G.E., \& Bishop, D. (2014). A grounded theory study of legitimacy work among ethics and compliance officers. Organizational Behavior and Human Decision Processes, 123, 186-205.

Uhl-Bien, M., Riggio, R.E., Lowe, K.B., \& Carsten, M.K. (2014). Followership theory: A review and research agenda. The Leadership Quarterly, 25(1), 83-104.

Uhl-Bien, M., Piccolo, R.F., \& Shermerhorn, J.R. (2020). Organisational behaviour, ( ${ }^{\text {nd }}$ Ed.). USA: Wiley.

Young, S. (2003). Moral Capitalism. California: Berrett-Koehler Publishers, Inc.

Yin, R.K. (2015). Qualitative Research from Start to Finish. New York: Cuilford Press.

Yu, A., Matta, F. K., \& Cornfield, B. (2018). Is Leader-member exchange differentiation beneficial or detrimental for group effectiveness? A meta-analytic investigation and theoretical integration. Academy of Management Journal, 61(3), 1158-1188.

Yukl, G. A. (2008). How leaders influence organizational effectiveness. The Leadership Quarterly, 19, 708-722.

Yukl, G. A. (2018). Leadership in Organisations. Global Edition. Pearson Education. 